\title{
Environmental entrepreneurship as a type of social entrepreneurship
}

\author{
Ulyana Filatova ${ }^{1, *}$ \\ ${ }^{1}$ Irkutsk State University, Ulan-Batorskaya str., 10, Irkutsk, 664082, Russia
}

\begin{abstract}
The article considers main problems of defining environmental entrepreneurship primarily as a legal phenomenon. The aim of the article is to search for meanings and mechanisms for understanding the legal category of "environmental entrepreneurship", to identify its content, to characterize subjects and to outline main directions of development of legislation governing environmental and entrepreneurial relations. The leading approach to the study of this problem is dialectics, analysis, synthesis, deduction, formal legal method and comparative legal method. Conclusions: The analysis can contribute to creation of developed environmental-entrepreneurial relations in Russia, which is achieved by building a verified conceptual and categorical apparatus, determining the model of legal regulation. The mechanisms of legal regulation require creation of special law and establishment of principle of priority of environmental organization of economic activity as the basic principle of entrepreneurship in general and determinant of legal regulation of environmental entrepreneurship in particular.
\end{abstract}

\section{Introduction}

Article 36 of the Constitution of Russian Federation lays down basic principle of attitude to natural resources for citizens and legal entities. Ownership, use and disposal of land and other natural resources are carried out by their owners freely, if this does not harm the environment and does not violate the rights and legitimate interests of other persons. This restriction of the right of ownership of natural objects at the highest legislative level reflects the "global trend of awareness of global systemic crisis, which primarily includes the environmental component and corresponds to the general vector of environmentalconservation orientation of modern constitutions."

Environmental problems concern not only politicians, but society as a whole. According to $48 \%$ of Russians, environmental pollution is the most dangerous of threats, second place is taken by global terrorism ( $42 \%$ of respondents), and armed conflicts and wars $(37 \%)$ are in third place. Global warming (34\%) and man-made disasters and accidents (31\%) were also mentioned by the respondents.

As the most serious of environmental problems for Russia, the respondents called air pollution $(26 \%)$. At the same time, percentage of people concerned about this problem has

*Corresponding author: filatova.uljana82@gmail.com 
decreased since 2010, which follows from the results of the study (there were $29 \%$ in 2010). On the contrary, over nine years, Russians began to worry more about the problems of disposing of household waste (17\% now, $8 \%$ in 2010$)$ and nuclear waste $(11 \%$ now, $8 \%$ in 2010). The number of people concerned about water pollution, on the contrary, decreased markedly from 15 to $9 \%$. Fear of genetically modified foods remained unchanged at $9 \%$.

President Vladimir Putin discussed the issue of ecology in a recent message to the Federal Assembly. He called on the business to "remember its social and environmental responsibility" and commissioned "to extend environmental monitoring throughout the country."

At the same time, according to the Russian ecological society, one of the existing problems of modern Russia is strengthening of state regulation in the environmental sphere. There is a problem on the one hand with the over-regulation of the environmental sphere, on the other hand, the lack of sufficiency of legal regulation. For example, there are no laws to ensure the effective operation of the environmental control system, including "On Environmental Control", "On Payments for Negative Impact on the Environment", "On Environmental Insurance", and "On Environmental Audit". Regulation of a private law sphere, namely the sphere of environmental entrepreneurship, is not carried out to the proper extent.

Environmental entrepreneurship is a new phenomenon for Russian law. The content of this term is not legally disclosed, which necessitates its doctrinal definition, identification of signs, features and justification of a regulatory model.

As noted in the scientific literature, various terms are used to refer to environmental entrepreneurship, most often as synonyms. Among them: "environmental entrepreneurship", "green entrepreneurship", "ecological entrepreneurship", "ecoentrepreneurship", and their derivatives "ecopreneurship", as well as "green-green business" [4].

Introducing the concept of environmental entrepreneurship into the legal field, Russian legal validity is obliged to the Model Law "On the Basics of Environmental Entrepreneurship" (Resolution N 15-6 of June 13, 2000). However, over the 20 years since the development and adoption of the model law, a special law of Russian Federation on environmental entrepreneurship has not been created, in addition, neither the Civil Code of Russian Federation nor the Federal Law "On Environmental Protection" have developed this area of lawmaking.

The purpose of the study is to search for meanings and mechanisms for understanding the legal category of environmental entrepreneurship, to identify types of activities that make up its content, and to identify the main directions of development of legislation governing environmental entrepreneurship.

The novelty of the study lies in formulation, justification and solution of the tasks of determining the category of environmental entrepreneurship, identifying the types of activities that make up its content, and identifying the main directions of development of legislation governing environmental entrepreneurship.

\section{Methods}

Empirical basis of the work. As already noted the beginning of legalization of the category of environmental entrepreneurship was received with adoption of the Model Law "On the basics of environmental entrepreneurship" by the CIS countries. According to the provisions of this document, environmental entrepreneurship means production, research, credit and financial activities for production of goods, performance of work and provision of services, with the intended purpose of ensuring preservation and restoration of 
environment and protection of natural resources. Thus, environmental entrepreneurship includes activities aimed at preserving, restoring and protecting the environment and resources. Further, defining products of environmental significance as an object of entrepreneurial activity, the concepts of protection and reproduction are used. The two concepts used before (conservation and restoration) are not mentioned, which does not contribute to the establishment of terminological uniformity, although, as is known, the model law serves precisely this purpose.

The subjects of environmental entrepreneurship are legal entities and entrepreneurs without formation of a legal entity, regardless of the legal form, carrying out activities for production of products, performance of work and environmental services. Article 4 of the same act specifies that subjects of environmental entrepreneurship are only those entrepreneurs whose production of environmental products is defined as the main activity in the charter documents and the share of these products is at least 75 percent of the total annual volume of production in value terms, which also specialize (have the main type of activity according to the charter documents) in performance of works and services for environmental protection.

The main direction of support of environmental entrepreneurship by the state is creation of a system of legal regulation of environmental entrepreneurship both at the federal level and at the level of constituent entities of Russian Federation. The system of environmental and business legislation would provide a basis for its development, consolidate guarantees, including tax incentives, special customs regimes, subsidies, other payments under environmental programs, and determine conditions for accreditation, certification and licensing of environmental business entities.

However, this very main task was not realized by Russian legislators. Signs of existence of environmental entrepreneurship in the legal field can only be detected by a detailed analysis of a number of normative legal acts scattered in the special system, as well as development programs and national projects.

The main law governing entrepreneurial activity in Russian Federation is the Civil Code; it does not contain a definition of environmental entrepreneurship, nor even an indication of the principle of doing business with the least possible harm to the environment. The Federal Law "On Environmental Protection" (N 7 dated 10.01.2002) in Article 17 formulated the principles of providing state support to environmental entrepreneurs. Particular attention should be paid to the fact that the law, firstly, does not use the term "environmental entrepreneurship", but mentions economic activity and other activities; secondly, it considers activities carried out for the purpose of environmental protection only, aimed at minimizing the negative impact of economic activity; thirdly, regulation is carried out only in the aspect of providing state support in form of tax benefits, reducing fees for negative environmental impacts, and subsidies.

A number of national programs trace the idea of ensuring environmental safety in the process of carrying out economic activities. So, for example, the main tasks of ensuring food security, regardless of changes in external and internal conditions, are, inter alia, development of agricultural production, raw materials and food, which correspond to established environmental ones; restoration and increase of fertility of agricultural land, prevention of reduction of agricultural land, rational use of such land, protection of agricultural land from water and wind erosion and desertification (Decree of the President of Russian Federation of January 21, 2020 No. 20 "On approval of the Food Security Doctrine").

Following scientific methods were used in the study: dialectics, analysis, synthesis, deduction, formal legal method, comparative legal method.

Dialectics allowed us to push away from general theoretical ideas and find a place for environmental entrepreneurship in general system of civil law. Analysis and synthesis made 
it possible to identify types of economic activity that can be considered environmental entrepreneurship. The use of formal legal method in the study made it possible to describe, generalize and systematize the category of environmental entrepreneurship. Comparative legal method made it possible to compare the concepts of "social entrepreneurship" and "environmental entrepreneurship", to identify similarities and differences between them.

\section{Results}

\section{Types of environmental entrepreneurship.}

As a rule, scientists distinguish different set of activities both directly and indirectly related to environmental protection. The main positions on this issue will be reflected in the table.

Table 1 Types of activities attributed to environmental entrepreneurship

\begin{tabular}{|c|c|}
\hline Authors & Activities related to environmental entrepreneurship \\
\hline A.V. Kurbatov & $\begin{array}{c}\text { - work on the study of the state of natural resource potential and the environment; } \\
\text { - provision of services to business entities (environmental inventory, development of draft standards for } \\
\text { maximum permissible emissions (MPE) and maximum permissible discharges (MPD) for enterprises, } \\
\text { expert advisory services, eco-audit services, etc .; } \\
\text { - Reclamation and reproduction of natural environment; } \\
\text { - production of environmental, resource-saving equipment and technological equipment, environment- } \\
\text { friendly products; } \\
\text { - ensuring the functioning of ecological infrastructure itself (repair and maintenance of environmental } \\
\text { protection machinery and equipment, training and retraining of personnel, rendering information services } \\
\text { on the environmental market, etc.) }\end{array}$ \\
\hline $\begin{array}{l}\text { A.P. Anisimov, } \\
\text { A.Ya. } \\
\text { Ryzhenkov, } \\
\text { A.E. } \\
\text { Chernomorets }\end{array}$ & $\begin{array}{l}\text { - development and implementation of environmental protection software used for public administration } \\
\text { and reporting; } \\
\text { - work and / or services for extraction, maintenance, sale, purchase, exchange, transfer, storage, export } \\
\text { abroad and import into the country of zoological and botanical collections, biological objects; } \\
\text {-Environmental auditing of production enterprises of nature users and business entities; } \\
\text { - adjustment and operation of environmental protection equipment, measuring instruments and control of } \\
\text { environmental parameters of industries and vehicles; } \\
\text { - environmental safety assessment of materials, substances, technologies, equipment, industrial plants and } \\
\text { industrial facilities; } \\
\text { - trade in quotas (permits) for emissions of harmful substances into the air; } \\
\text { - exchange of state debts for environmental activities (creditors write off part of the debts to debtors in } \\
\text { exchange for their obligation to send appropriate funds for environmental measures), etc. }\end{array}$ \\
\hline Bekisheva S.D. & $\begin{array}{l}\text { - provision of environmental information services (environmental monitoring, provision of environmental } \\
\text { information, expert advisory services, environmental inventories, maintaining natural resource inventories, } \\
\text { development of draft standards for maximum permissible emissions (MPE) and maximum permissible } \\
\text { discharges (MPD) for enterprises); } \\
\text { - environmental impact assessment (environmental safety assessment of materials, substances, } \\
\text { technologies, equipment, industrial plants and industrial facilities, environmental audit); } \\
\text { - environmental consulting, i.e. a range of activities related to the environmental support (provision) of } \\
\text { activities of enterprises and other entities, which includes development of resource-saving projects, } \\
\text { reduction of environmental pollution by enterprises, planning of environmental events, etc .; } \\
\text { - provision of "environmental capital", i.e. banking, financing, investment of environmental events, } \\
\text { projects; } \\
\text { - production of environmental, resource-saving equipment, machines, devices, environmentally friendly } \\
\text { technologies); } \\
\text { - production of environmentally friendly products (food products without the use of pesticides, synthetic } \\
\text { fertilizers and growth stimulants, self-decomposing packaging, etc.); } \\
\text { - use of renewable energy sources; } \\
\text { - development of ecological tourism; } \\
\text { - utilization of industrial and household waste; } \\
\text { - reproduction of natural environment (restoration of flora and fauna, cleaning of water bodies, lands, etc.); } \\
\text { - services on rehabilitation of territories, liquidation of consequences of accidents; } \\
\text { - provision of educational environmental services (training and retraining of personnel, advanced training). }\end{array}$ \\
\hline
\end{tabular}

In our opinion, in determining the lists of types of environmental activity, one should be guided by the principle of an open list and only a formula should be set that allows one to attribute economic activity to environmental activities. Environmental entrepreneurs are those individuals and legal entities that provide an environmental service, or produce an environmental product, or develop an enterprise and manage it on the basis of 
environmental principles. This formula will avoid unnecessary detailing, which in turn can always be considered incomplete.

2. Mechanism of legal regulation of environmental entrepreneurship.

First of all, this is the question of what environmental entrepreneurship means: a special type of entrepreneurial activity or a principle of any entrepreneurial activity. Both are reflected in the laws of various states and involve different mechanisms of legal regulation. So, for example, G.A. Pisarev proposes establishment of a basic principle of entrepreneurial activity in general and a principle of entrepreneurial law as an industry - the principle of priority of environmental organization of economic activity, which will be one of the main regulators. This approach is embodied in the Entrepreneurial Code of the Republic of Kazakhstan. The Republic of Kazakhstan does not isolate a social entrepreneur as a special subject of entrepreneurial relations, but imposes social responsibility on the business as a whole. This position, on the one hand, is consistent with the modern approach, according to which the reduction of entrepreneurship to commerce is erroneous. Social responsibility of entrepreneurship is a voluntary contribution of business entities to the development of social, environmental and other areas.

The Entrepreneurial Code names 4 areas where social responsibility of entrepreneurship can manifest itself. These are the areas of employment and labor relations, environmental protection and other areas.

Thus, legal regulation of environmental entrepreneurship in the Republic of Kazakhstan is more likely to focus on the social mission of business as a whole, nurture a conscious attitude of entrepreneurs to the environmental sphere and stimulate entrepreneurship in the implementation of environmental projects.

In Russian law, social mission of entrepreneurship is associated with the activities of social enterprises. In July 2019, the concepts of social entrepreneurship and social enterprise were enshrined in the Federal Law "On Development of Small and Mediumsized Enterprises". Social entrepreneurship refers to activities aimed at achieving socially useful goals that contribute to solving social problems of citizens and society. A social enterprise is a subject of small and medium-sized businesses that operates in the field of social entrepreneurship.

One of the key points distinguishing social enterprises is that they carry out entrepreneurial activity. It is primary that this activity is aimed at systematic receipt of profit, and the quality feature distinguishing it from other types of entrepreneurship is their focus on achieving socially useful goals, but the first key factor is forcing entrepreneurs to go at least to the level of self-sufficiency and sustainability in terms of their own income. Therefore, abroad, the subject of law is not considered a social enterprise if it exists only thanks to grants, subsidies, donations, contributions of the founder. Without a sign of selfsufficiency, there is no social enterprise, because first of all it is a business.

Social enterprises include those small and medium-sized businesses providing:

1) labor integration (employment of persons with disabilities, single or large family parents, pensioners, refugees etc. the list is open (their share of the total number of employees is 50 percent, and labor costs are at least 25 percent);

2) sale of goods produced by persons from the above-mentioned list with the share of income from such activities not less than 50 percent;

3) production of goods for the above-mentioned persons in order to compensate for limitations of their life;

4) activities aimed at achieving socially useful goals (pedagogical and social services, organizing recreation for children, training of workers and volunteers, cultural and educational activities, preschool and school education of children).

Thus, Russian law does not classify environmental entrepreneurship among social entrepreneurship. But European experience indicates the opposite, and ranks environmental 
protection as social entrepreneurship along with integration of work, personal social services, and local development of disadvantaged areas.

Exclusion of environmental entrepreneurship from the social one deprived environmental entrepreneurs of the opportunity to rely on guarantees provided to social entrepreneurs which are provided with support in form of infrastructure availability, financial, property, consulting and methodological and others.

\section{Discussion}

The lack of law, as well as different approaches to definition of environmental entrepreneurship in legal sources, gave rise to a scientific discussion on the content of the term "environmental entrepreneurship".

So, according to E.V. Varennikova, environmental entrepreneurship includes initiative economic activity, taking into account environmental requirements and restrictions, aimed at avoiding (reducing) negative environmental impact, as well as improving environmental performance in order to maximize profits. It is proposed to consider the criteria for classifying entrepreneurs as environmentally oriented as "introduction of environmental management systems in their economic activities, use of a significant share of economic innovations, significant role of environmental utility in overall utility of results of their activities. S.V. Zlobin defines environmental entrepreneurship as a socially significant, independent, initiative activity of individuals associated with conscious assumption of potential risk of unprofitable consequences in production of environmental products, which consists in conducting research, credit and financial activities, and performing environmentally significant work and provision of services aimed at generating profit (income). In general, agreeing with the position of S.V. Zlobin A.Ya. Ryzhenkov offers his definition of environmental entrepreneurship, which is based on the definition of the Model Law. So the author writes that environmental entrepreneurship is the activity of citizensentrepreneurs and legal entities aimed at production of goods, performance of work and provision of services to prevent, limit or eliminate negative environmental impacts.

\section{Conclusion}

1. At present, Russian environmental entrepreneurship does not have legal regulation. Referring to the norm of the Constitution of Russian Federation and general provisions of the Law "On Environmental Protection", we can only talk about creating a certain principle of economic activity, taking into account the priority of environmental organization of economic activity, which is not directly fixed, but derived as a result of interpretation of legislative requirements. Failure to classify environmental entrepreneurship as an option of social entrepreneurship has deprived environmental entrepreneurs of the opportunity to rely on guarantees provided to social entrepreneurs who are guaranteed with support in form of infrastructure, financial property, consulting, methodological and other. Low level of development of legislation plays the role of an external factor constraining environmental entrepreneurship.

2. Definition of lists of types of environmental entrepreneurship by listing the types of entrepreneurial activity directly or indirectly related to the environment seems unjustified. By determining the lists of types of environmental activity, one should be guided by the principle of an open list and only a formula should be set allowing one to attribute economic activity to environmental activities. Environmental entrepreneurs are those individuals and legal entities that provide an environmental service, or produce an environmental product, or develop an enterprise and manage it on the basis of 
environmental principles. This formula will help avoiding unnecessary detailing, which in turn can always be considered incomplete.

The reported study was funded by RFBR, project number 20-011-00222.

\section{References}

1. U. Filatova, N. Semeryanova, S. Suslova, A. Gabudina, A. Kopytova, E3S Web of Conferences 91, 08071 (2019) DOI: https://doi.org/10.1051/e3sconf/20199108071

2. N.A. Zulkefly, N.A. Ghani, W. Alquliti, Journal of Physics: Conference Series 1339(1), 012025 (2019) DOI: 10.1088/1742-6596/1339/1/012025

3. V. Jafari-Sadeghi, S. Kimiagari, P.P. Biancone, European Business Review 32(1), 4668 (2019) DOI: 10.1108/EBR-05-2018-0098

4. N.J. Pearse, J. Peterlin, Journal of Research in Marketing and Entrepreneurship 21(2), 149-162 DOI: 10.1108/JRME-07-2018-0036

5. D. Izvin, V. Lez'Er, A. Kopytova, MATEC Web of Conferences, 170, 01065 (2018) DOI: $10.1051 / \mathrm{matec}$ onf $/ 201817001065$

$\begin{array}{lllllll}\text { 6. S. Song, S. Lee Tourism Management } & \text { 78, } 104050 \quad \text { (2020) }\end{array}$ DOI: $10.1016 /$ j.tourman.2019.104050

7. A. Kopytova, MATEC Web of Conferences 106, 08056 (2017) DOI: 10.1051/matecconf/201710608056

8. M. Hamirul Hamizan Roslan, S. Hamid, M. Taha Ijab, S. Bukhari, Journal of Physics: Conference Series 1339(1), 012029 (2019) DOI: 10.1088/1742-6596/1339/1/012029

9. V. Lez'Er, N. Semerianova, A. Kopytova, Y. Truntsevsky, E3S Web of Conferences 110, 02093 (2019) DOI: 10.1051/e3sconf/201911002093

10. S. Scaramuzzi, G. Belletti, P. Biagioni, Agricultural and Food Economics 8(1), 5 (2020) DOI: 10.1186/s40100-019-0150-8

11. R. Bouncken, M.M. Aslam, Journal of Knowledge Management 23(10), 2067-2085 (2019) DOI: 10.1108/JKM-05-2018-0316

12. V.A. Lez'Er, N.A. Semeryanova, A.V. Kopytova, MATEC Web of Conferences, 239, 04027 (2018) DOI: 10.1051/matecconf/201823904027

13. J.L. Caton, Journal of Entrepreneurship and Public Policy 8(4), 442-469 (2019) DOI: $10.1108 /$ JEPP-D-18-00084 